\title{
Impact of sugar beet seed priming on seed quality and performance under diversified environmental conditions of germination, emergence and growth
}

\author{
C. Chomontowski ${ }^{1} \cdot$ H. Wzorek ${ }^{1} \cdot$ S. Podlaski ${ }^{1}$ \\ Received: 16 October 2018 / Accepted: 23 April 2019 / Published online: 3 May 2019 \\ (c) The Author(s) 2019
}

\begin{abstract}
In the presented work attempts have been made to explore effectiveness of the sugar beet (Beta vulgaris L.) seeds priming process in relation to seed quality and environmental conditions. This study was conducted in three different field stations in the years 2013-2015 using two lots of sugar beet seeds of the variety Janosik that differed in their level of vigour. In the laboratory and phytotron experiments, pelleted and non-pelleted seeds were used while in the field experiments only pelleted seeds were used. Seed priming was carried out using two patented technologies based on the solid matrix priming method. The results of this study indicate that pelleting can reduce both seed viability and rate of germination, especially in the early stages. Both priming methods positively influenced seed germination ability and speed. The efficiency of priming was higher in seeds with lower vigour than those with higher vigour. It follows that priming seeds, especially those with lower vigour is particularly efficient. As a result, seed loss during treatment can be reduced. The obtained data indicate that priming reduces the differences in germination and the course of emergence caused by different levels of seed vigour and germination conditions. The higher vigour of seeds caused by priming was associated with the acceleration of leaf development and the increase in plant dry matter during the growing season. As a result, seed priming contributes to a significant increase in the technological yield of sugar. It should also be noted that the average weight of single root is less variable during harvesting.
\end{abstract}

Keywords Sugar beet $\cdot$ Seeds vigour $\cdot$ Seeds priming $\cdot$ Root yield

\section{Introduction}

Many recent studies have shown that crops and their quality are increasingly determined by genetic progress (varieties) as well as the somatic value (vigour) of seeds (Fischer and Edmeades 2010, Barnes et al. 2016, Noleppa 2016). Among the new technologies of seed enhancement, priming is beginning to play a major role. Seed priming is a controlled hydration process that triggers metabolic processes during the early phases (I and II) of germination before radicle protrusion (Hussain et al. 2016). This process involves advancing individual seeds within a seed lot to the same

C. Chomontowski

chrystian_chomontowski@sggw.pl

1 Department of Plant Physiology, Faculty of Agriculture and Biology, Warsaw University of Life Sciences SGGW, 159 Nowoursynowska St., 02-776 Warsaw, Poland stage in the germination process to enable fast and uniform emergence after planting.

Although the individual effects of priming are already known, there has still been a lack of a holistic approach to the understanding of this process including metabolomics, proteomics and transcriptomics aspects (Lutts et al. 2016). The main effects of seed priming are the acceleration of germination and plant emergence and sometimes the improvement of seed viability and the acceleration of seedling growth (Khan 1992). The British Germains Seed Company has achieved a $50 \%$ reduction in the plant emergence time by using seed priming (Burks 2008). The economic effects of sugar beet seed priming in the UK have resulted in a $4 \%$ root yield gain and a technological yield of sugar of 5\% (Jaggard et al. 2009). After summarizing the results obtained from 18 sites in Poland during the years 2006-2009, the results showed an increase of $3.8 \%$ in root yield obtained from primed seeds, with an average yield of $7.74 \mathrm{t} \mathrm{ha}^{-1}$, and an increase in the technological yield of sugar by $3.4 \%$, with an average yield of $11.22 \mathrm{t} \mathrm{ha}^{-1}$ (Podlaski et al. 2010). 
The increase in yield as a result of priming may be due to improved plant density and increased radiation interception, especially as a result of accelerated leaf development. A reduction from the baseline value of $120^{\circ} \mathrm{Cd}$ (thermal time) for $50 \%$ of seedlings to emerge to $90^{\circ} \mathrm{Cd}$ has just been introduced by the application of Germains XBEET priming technology (Burks 2008). A further reduction to $80^{\circ} \mathrm{Cd}$ should be possible, which could increase sugar yield by approximately $0.3 \mathrm{t} \mathrm{ha}^{-1}$ compared with the seed used in England in 2007 (Burks 2008). According to the last seed survey (2017/18), the International Confederation of European Beet Growers' (CIBE 2017) share of primed seed is increasing in the EU market. All sugar beet seeds in the Czech Republic, the Netherlands, Slovakia and the United Kingdom are primed.

Draycott (2006) stated that the priming of sugar beet seeds increases the germination speed and plant emergence but that the final plant density remains unchanged. Consequently, the use of primed seeds allows the sowing time in Western Europe to occur approximately 10 days earlier, which contributes to a prolonged vegetation period and an increase in sugar yield of approximately 5\%. Most studies on seed priming have addressed seed germination and/or early seedling growth. Data showing the effects of seed priming under field conditions remain rare. Quite often, the results of priming vary depending on the seed treatment technology used and the variety, quality (vigour) and physiological maturity of the seeds (Paparella et al. 2015).

Therefore, it is advisable to undertake research on the evaluation of the effectiveness of different methods of seed treatment in relation to the initial seed vigour under different environmental conditions.

\section{Materials and Methods}

\section{Plant Material}

This study was conducted in the years 2013-2015 using two lots of sugar beet seeds of the variety Janosik that differed in their level of vigour. Data on the variation in vigour are included in the tables: 2, 4, 5 and 6. In the laboratory and phytotron experiments, seeds pelleted using Kutnowska Hodowla Buraka Cukrowego Sp z o. o. (KHBC) technology (standard pellet for sugar beet) and non-pelleted seeds were used. Only pelleted seeds were used in the field experiments. Seed priming was carried out using two patented methods: Quick Beet (QB) Patent No. P207240 and Quick Beet 1 (QB-1) Patent No. P218893. Priming was based on the solid matrix priming (SMP) method, with the use of zeolites as water carriers. The analysis of seed germination was carried out according to ISTA standards (PN-79/R-65950) (ISTA 1995) at temperatures of $10{ }^{\circ} \mathrm{C}$ and $15{ }^{\circ} \mathrm{C}$ and three levels of filter paper water holding capacity, $40 \%$ FWC (shortage), $60 \%$ (optimum) and $80 \%$ (excess) water, in the germination media. To assess the germination and plant emergence speed, the mean germination/emergence time (MGT/MET) was calculated according to the following formula (Pieper and Eggebrecht 1952):

$\mathrm{MGT} / \mathrm{MET}=\frac{\Sigma\left(d_{n} \times a_{n}\right)}{\Sigma a_{n}}$

where $d_{n}$ is the current emergence day, and $a_{n}$ is the number of emerged plants on the current day.

\section{Analysis of the Plant Growth Course in the Phytotron}

This experiment was carried out at $15{ }^{\circ} \mathrm{C}$ and $60 \%$ of the full (optimal) water capacity of the soil in a Siemens phytotron chamber at Warsaw University of Life Sciences. Seeds were sown in garden soil at $2 \mathrm{~cm}$ depth, and 3 replicates of 20 seeds each were used. HOBO U23-001 temperature and humidity sensors were placed at $2 \mathrm{~cm}$ depth to monitor the germination conditions.

\section{Analysis of Plant Growth Under Field Conditions}

The quality of the seeds from the two lots was evaluated in the WULS laboratory, while plant growth and root yield were determined at 3 experimental stations in Skierniewice $\left(51^{\circ} 57^{\prime} \mathrm{N}, 20^{\circ} 9^{\prime} \mathrm{E}\right)$, Śmiłów $\left(50^{\circ} 50^{\prime} \mathrm{N}, 21^{\circ} 41^{\prime} \mathrm{E}\right)$ and Straszków $\left(52^{\circ} 15^{\prime} \mathrm{N}, 18^{\circ} 55^{\prime} \mathrm{E}\right)$. The soil at Skierniewice is a Stagnic Luvisol, and that at Straszków is a Grey-Brown Podzolic. The soil at Śmiłów may be classified as Haplic Luvisols developed from loesses. The relative growth rate (RGR) was estimated according to Evans formula (Evans 1972).

\section{Weather Conditions}

The mean annual total precipitation in Poland in the years of 1971-2010 was $611 \mathrm{~mm}$, while the mean annual air temperature was $7.9^{\circ} \mathrm{C}$. In the years of 2013-2015, the mean precipitation in Skierniewice, Straszków and Śmiłów ranged from $525 \mathrm{~mm}$ in 2015 to $635 \mathrm{~mm}$ in 2013, while the temperature ranged from $8.4{ }^{\circ} \mathrm{C}$ in 2013 to $9.8^{\circ} \mathrm{C}$ in 2015 . These data indicate that the average rainfall was lower or higher and that the temperature was higher than the multi-year average in the years of the study. The assessment of field emergence was carried out in four replicate plots in which one hundred seeds were hand sown. After the beginning of emergence, the plants were counted every 2 days to determine the speed of emergence. To estimate growth and root yield, seeds were 
sown every $15 \mathrm{~cm}$ in a row with a precision drill, with $50 \mathrm{~cm}$ between the rows. The seeds were fertilized with 140-160 N without manure, 40-60 P or 100-125 K depending on the soil fertility. The size of the plot was $30 \mathrm{~m}^{2}$. The roots were harvested in October using a combine harvester. After the harvest, the sugar beets were transported to the laboratory, where the yield and root parameters were evaluated on an automatic Venema line. During the vegetative period, 20 plants were collected 61-69 days after sowing, 82-88 DAS, 112-116 DAS and 146-153 DAS (4 times) from each experimental treatment for the assessment of fresh and dry matter. In addition, the leaf area index (LAI) was calculated. At harvest, the root coefficient of variation was determined by analysing the weight of roots.

\section{Statistical Analysis}

The acquired data were analysed using Tukey's test $(p<0.05)$ in the Statgraphics Centurion programme (version 17.1.08) and analysis of variance (single or dichotomous) in the ANOVA programme.

\section{Results}

The priming of pelleted and non-pelleted seeds increased the germination ability evaluated after 14 days from 3.2 to $4.5 \%$ on average in relation to the control seeds. The Quick Beet and Quick Beet 1 seeds germinated significantly faster by 1.02 and 1.15 days, respectively, compared to the nonprimed seeds. These data indicate that seed priming primarily influenced the germination speed.
The pelleting of control seeds decreased their germination ability after 14 days by $7.1 \%$, while the germination ability of QB and QB-1 seeds decreased by 4.0 and $4.1 \%$, respectively. This result demonstrates the partial elimination of the negative influence of pelleting on seed viability by priming. A reverse pattern occurred in the case of the germination rate. The pelleting of control seeds decreased the germination speed by 1.55 days, while that of QB and QB-1 seeds decreased by 1.98 and 2.2 days, respectively (Table 1 ).

The priming of seeds with high and low vigour using the QB and QB-1 methods significantly increased their germination ability by an average of 5.2 and $6.5 \%$ and their germination speed by an average of 1.07 and 1.27 , respectively, in relation to the control seeds (Table 2). At the same time, the seeds primed using both the QB and QB-1 methods were characterized by smaller differences in their germination ability and speed between the two levels of vigour than the non-primed seeds. The difference in the germination ability of QB-1-treated seeds with high and low vigour was only $1.2 \%$, while that in the control seeds was $4.8 \%$. The differences in germination rate were 0.75 and 1.14 days, respectively. The priming of seeds with low vigour using the $\mathrm{QB}$ and QB-1 methods increased their germination ability by 7.6 and $9.3 \%$, respectively, compared to 4.8 and $5.7 \%$ in the seeds with high vigour. A similar trend occurred for the germination speed. The above data indicate that in the assessment of germination ability after 14 days (seed viability), the efficacy of priming seeds with low vigour was higher than that in seeds of higher vigour. As a result, the primed seeds with low vigour are characterized by better germination parameters (ability and speed) than non-primed seeds with high vigour (Table 2).
Table 1 The ability (\%) and speed of seed germination (days) of pelleted and nonpelleted seed in relation to the seed treatment after 14 days
Table 2 Pelleted high and low vigour seed germination ability (\%) and speed (days) after 14 days at $10{ }^{\circ} \mathrm{C}$

\begin{tabular}{|c|c|c|c|c|c|c|}
\hline \multirow[t]{2}{*}{ Priming method } & \multicolumn{3}{|c|}{ Germination ability (\%) } & \multicolumn{3}{|c|}{ Germination speed (days) } \\
\hline & Pelleted & Non-pelleted & Average & Pelleted & Non-pelleted & Average \\
\hline Control & $88.7 \mathrm{a}$ & $95.8 \mathrm{ab}$ & $92.3 \mathrm{a}$ & $6.76 b c$ & $5.21 \mathrm{ac}$ & $6.00 \mathrm{bc}$ \\
\hline Quick Beet & $93.5 \mathrm{ab}$ & $97.5 b$ & $95.5 b$ & $5.97 \mathrm{~b}$ & 3.99ab & $4.98 \mathrm{~b}$ \\
\hline Quick Beet 1 & $94.7 \mathrm{ac}$ & $98.8 \mathrm{bc}$ & $96.8 \mathrm{c}$ & $5.75 \mathrm{ab}$ & $3.55 \mathrm{a}$ & $4.85 \mathrm{ab}$ \\
\hline Average & $92.3 \mathrm{a}$ & $97.4 \mathrm{~b}$ & $x$ & $6.16 \mathrm{~b}$ & $4.25 \mathrm{a}$ & $x$ \\
\hline
\end{tabular}

Averages from 3 years, 3 levels of filter paper moisture and 2 levels of seed vigour at a temperature of $10{ }^{\circ} \mathrm{C}$ are presented

\begin{tabular}{|c|c|c|c|c|c|c|}
\hline \multirow[t]{2}{*}{ Priming method } & \multicolumn{3}{|c|}{ Germination ability (\%) } & \multicolumn{3}{|c|}{ Germination speed (days) } \\
\hline & Low vigour & High vigour & Average & Low vigour & High vigour & Average \\
\hline Control & $85.3 \mathrm{a}$ & $90.1 \mathrm{ab}$ & $88.7 \mathrm{a}$ & $8.84 b$ & 7.70a & $8.27 \mathrm{c}$ \\
\hline QB & $92.9 \mathrm{~b}$ & $94.9 \mathrm{~b}$ & $93.9 \mathrm{~b}$ & $7.52 \mathrm{a}$ & $6.88 \mathrm{c}$ & $7.20 \mathrm{~b}$ \\
\hline QB-1 & $94.6 \mathrm{~b}$ & $95.8 \mathrm{~b}$ & $95.2 \mathrm{~b}$ & $7.41 \mathrm{a}$ & $6.66 \mathrm{~d}$ & $7.00 \mathrm{a}$ \\
\hline Average & $90.9 \mathrm{a}$ & $93.6 \mathrm{a}$ & $x$ & $7.92 \mathrm{~b}$ & $7.08 \mathrm{a}$ & $x$ \\
\hline
\end{tabular}

Averages from 3 years and three filter paper moisture levels are presented 
Regardless of the temperature and moisture level of the filter paper, priming using the Quick Beet method significantly increased the germination speed by 0.87 and 1.06 days in comparison to the control seeds. Based on the data in Table 3, the average germination speed at $10{ }^{\circ} \mathrm{C}$ was calculated to be 7.45 days, and that at $15^{\circ} \mathrm{C}$ was calculated to be 4.89 days. A water shortage in the filter paper significantly decreased the germination speed by 0.98 days in relation to the optimal conditions, while excess water decreased the germination speed by 0.68 days. Priming reduced the negative effects of the $10{ }^{\circ} \mathrm{C}$ temperature and suboptimal moisture conditions on the germination rate. The germination temperature of $10{ }^{\circ} \mathrm{C}$ decreased the germination speed of the control seeds by 3.67 and 3.23 days at 40 and $80 \%$ WHC, respectively, in relation to the temperature of $15^{\circ} \mathrm{C}$. Priming using the QB and QB-1 methods reduced this difference from 2.93-2.95 days to 2.67-2.63 days. Under optimal humidity conditions, seed priming using the QB and QB-1 methods increased the germination rate by 0.67 and 0.81 days, respectively, in relation to the control seeds. However, under conditions of water shortage and excess, this increase was 1.17-1.27 days and 1.08-1.10 days, respectively (Table 3).

The priming of seeds using the QB and QB-1 methods increased the initial plant emergence course almost twice as much as the control seeds and increased the emergence speed from 0.24 to 0.27 days. Primed seeds with low vigour were characterized by a similar emergence course to that of non-primed seeds with high vigour. However, the emergence rate of plants grown from seeds with low vigour after priming was significantly lower than of plants from seeds with high vigour. The emergence course and speed of plants grown from non-primed seeds with high vigour were $26.0 \%$ higher and 0.76 days faster, respectively, compared to those grown from seeds with low vigour. Seed priming reduced these differences to $15.1-16.3 \%$ and $0.60-0.72$ days, respectively. It can therefore be concluded that seed priming not only significantly improves the emergence course and increases the germination ability but also eliminates qualitative differences caused by difference in seed vigour (Table 4).

Both methods of seed priming resulted in an increase in final field emergence. The QB method increased the final field emergence by $4.7 \%$ in comparison to the standard seeds, and the QB-1 method increased the final field emergence by $6.5 \%$. Priming using the QB and QB-1 methods significantly accelerated the course of field plant emergence by 0.40 and 0.46 days, respectively, in relation to the standard seeds. The level of seed vigour did not affect the final field emergence or plant population before harvest (data not shown), but it had a significant impact on the speed of plant emergence. Plants grown from seeds of high vigour were characterized by faster field emergence compared to seeds with low vigour by an average of 0.33 days. Plants grown from seeds with low vigour were characterized by faster field emergence than standard seeds with high vigour (Table 5).

The leaf area index (LAI) reached its maximum value $\left(4.5 \mathrm{~m}^{2} \mathrm{~m}^{-2}\right)$ approximately $112-116$ days after sowing (DAS). For the plants harvested during the 1st and 2nd harvesting periods, seed priming caused a significant increase in
Table 3 Germination speed (days) of pelleted seeds after 14 days in relation to the filter paper moisture level (40, 60 and $80 \% \mathrm{WHC}$ ) and temperature $\left(10{ }^{\circ} \mathrm{C}\right.$ and $\left.15^{\circ} \mathrm{C}\right)$ at which germination occurred
Table 4 Early plant emergence ability and speed of emergence for non-pelleted seeds in the phytotron in relation to seed vigour and treatment

\begin{tabular}{|c|c|c|c|c|c|c|c|c|c|c|}
\hline \multirow[t]{3}{*}{ Priming method } & \multicolumn{3}{|c|}{$80 \%$ WHC } & \multicolumn{3}{|c|}{$60 \% \mathrm{WHC}$} & \multicolumn{3}{|c|}{$40 \% \mathrm{WHC}$} & \multirow[t]{3}{*}{$x$} \\
\hline & \multicolumn{9}{|c|}{ Temperature } & \\
\hline & $10{ }^{\circ} \mathrm{C}$ & $15{ }^{\circ} \mathrm{C}$ & Average & $10^{\circ} \mathrm{C}$ & $15{ }^{\circ} \mathrm{C}$ & Average & $10^{\circ} \mathrm{C}$ & $15^{\circ} \mathrm{C}$ & Average & \\
\hline Control & 9.27 & 5.60 & 7.44 & 6.87 & 5.44 & 6.16 & 8.46 & 5.23 & 6.85 & $6.81 \mathrm{c}$ \\
\hline QB & 7.74 & 4.79 & 6.27 & 6.36 & 4.62 & 5.49 & 7.40 & 4.73 & 6.07 & $5.94 b$ \\
\hline QB-1 & 7.63 & 4.7 & 6.17 & 6.27 & 4.43 & 5.35 & 7.06 & 4.43 & 5.75 & $5.75 \mathrm{a}$ \\
\hline Average & 8.21 & 5.03 & 6.63 & 6.50 & 4.83 & 5.67 & 7.64 & 4.80 & 6.35 & $x$ \\
\hline$x$ & \multicolumn{3}{|l|}{$6.62 c$} & \multicolumn{3}{|l|}{$5.67 \mathrm{a}$} & \multicolumn{3}{|l|}{$6.35 b$} & \\
\hline
\end{tabular}

Averages from 3 years are presented

\begin{tabular}{llllllll}
\hline Priming method & \multicolumn{2}{l}{ Emergence ability $(\%)$} & & \multicolumn{2}{l}{ Emergence speed (days) } \\
\cline { 2 - 3 } & Low vigour & High vigour & Average & & Low vigour & High vigour & Average \\
\hline Control & $18.5 \mathrm{a}$ & $44.5 \mathrm{ab}$ & $31.5 \mathrm{a}$ & & $11.61 \mathrm{bc}$ & $10.85 \mathrm{ab}$ & $11.23 \mathrm{~b}$ \\
QB & $45.6 \mathrm{ab}$ & $61.9 \mathrm{~b}$ & $53.8 \mathrm{~b}$ & & $11.35 \mathrm{~b}$ & $10.63 \mathrm{a}$ & $10.99 \mathrm{a}$ \\
QB- 1 & $48.5 \mathrm{ab}$ & $63.6 \mathrm{~b}$ & $56.1 \mathrm{~b}$ & & $11.20 \mathrm{ab}$ & $10.60 \mathrm{a}$ & $10.96 \mathrm{a}$ \\
Average & $37.5 \mathrm{a}$ & $56.7 \mathrm{~b}$ & $X$ & & $11.39 \mathrm{~b}$ & $10.69 \mathrm{a}$ & $x$ \\
\hline
\end{tabular}

Emergence evaluated for 19 days after the beginning of plant emergence start; temperature $10{ }^{\circ} \mathrm{C}$ 
Table 5 Sugar beet field emergence course

\begin{tabular}{lllll}
\hline Priming method & $\begin{array}{l}\text { Final field } \\
\text { emergence } \\
(\%)\end{array}$ & \multicolumn{2}{l}{ Speed of field emergence (days) } \\
\cline { 3 - 5 } & Low vigour & High vigour & Average \\
\hline Control & $79.7 \mathrm{a}$ & $12.74 \mathrm{a}$ & $12.32 \mathrm{a}$ & $12.53 \mathrm{~b}$ \\
QB & $84.4 \mathrm{a}$ & $12.23 \mathrm{a}$ & $12.03 \mathrm{a}$ & $12.13 \mathrm{a}$ \\
QB-1 & $86.2 \mathrm{~b}$ & $12.26 \mathrm{a}$ & $11.88 \mathrm{a}$ & $12.07 \mathrm{a}$ \\
Average & 83.4 & $12.41 \mathrm{~b}$ & $12.08 \mathrm{a}$ & $X$ \\
\hline
\end{tabular}

Averages from 3 sites and years are presented

the LAI value: in the first period by $0.35(\mathrm{QB})$ and $0.51 \mathrm{~m}^{2}$ $\mathrm{m}^{-2}$ (QB-1) and in the second period by $0.55(\mathrm{QB})$ and $0.65 \mathrm{~m}^{2} \mathrm{~m}^{-2}$ (QB-1) in relation to the control plants. In period 3 (112-116 DAS), the highest LAI value was found in plants grown from primed seeds (Fig. 1). Plants grown from seeds with high vigour were characterized by a higher LAI index, although the differences were not significant (data not shown). A larger leaf area was associated with an increased dry weight of plants harvested at 45, 60 and 85 DAS. At any given time, plants grown from the QB1-primed seeds were characterized by a significantly higher (12.8-15.6\%) dry weight in relation to those grown from standard seeds (Fig. 2). There were no significant differences in RGR among the different harvest dates in relation to the seed treatment or level of vigour (data not shown). The course of field emergence depending on the level of seed vigour and treatment did not affect the planting density, which varied from 85-95,000 plants per hectare depending on the study year and site (data not shown).

The root yield varied widely during the years of the study. In 2013 in Straszków, and especially in Skierniewice, excessive one-off precipitation (115-120 mm) occurred, which lowered the root yield. This occurrence was likely the reason for the lack of positive effects of seed priming on the root yield in 2013. Under the more favourable growth

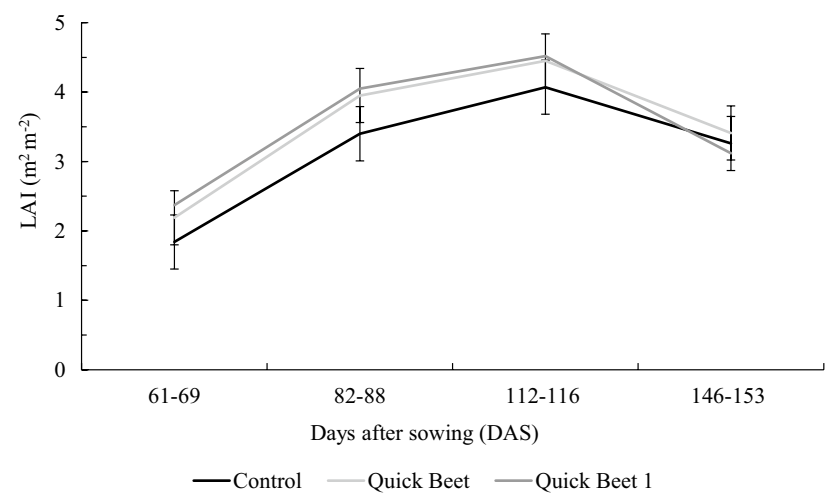

Fig. 1 Leaf area index during different periods of plant growth; averages of 2 vigour levels and 3 years

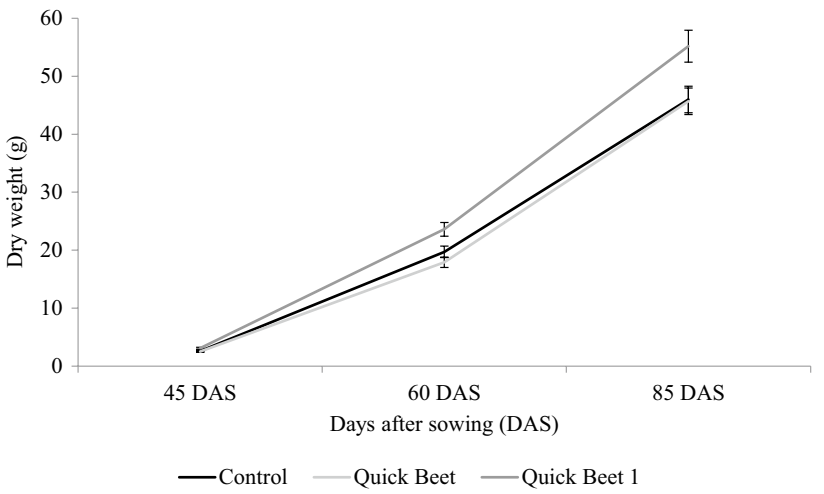

Fig. 2 Dry weight during different periods of plant growth; averages of 2 vigour levels and 3 years

conditions in 2014 and 2015, seed priming, particularly the QB-1 method, increased the root yield from 5.1 to $8.8 \mathrm{tha}^{-1}$ $(6.7-13.4 \%)$ in relation to the plants grown from standard seeds. Over the three years, seed priming using the QB and QB-1 methods increased the root yield from 2.5 (3.9\%) to $4.7 \mathrm{t} \mathrm{ha}^{-1}(7.3 \%)$, respectively, on average. There were no significant differences in the root yield of plants obtained from seeds with low or high vigour. However, in each year of the study, the root yield of plants from seeds with high vigour was $0.6-3.2(1.1-4.9 \%) \mathrm{t} \mathrm{ha}^{-1}$ greater than that of plants from seeds with low vigour (Table 6). The seed treatment influenced the root coefficient of variation determined at harvest time. This value was significantly the highest for control seeds (standard) (52.6\%), while the value for seeds primed using the QB and QB-1 methods was 47\% (Table 7).

The technological yield of sugar ranged from $9.29 \mathrm{t} \mathrm{ha}^{-1}$ in 2015 to $13.38 \mathrm{t} \mathrm{ha}^{-1}$ in 2014. Priming tended to increase the percentage of sugar content in relation to standard seeds. The increase in root yield and the percentage of sugar content, although not always statistically significant, increased the technological yield of sugar. The QB method non-significantly increased the sugar yield by $0.31 \mathrm{t} \mathrm{ha}^{-1}(2.8 \%)$ compared to the standard seeds, and the QB-1 method increased the sugar yield by $0.79 \mathrm{t} \mathrm{ha}^{-1}(7.3 \%)$. The effectiveness of priming high-vigour seeds using the QB-1 method was found to be higher than that of priming lower-vigour seeds. Regardless of the priming method used, the lower vigour of seeds significantly decreased the technological yield of sugar by $0.81 \mathrm{t} \mathrm{ha}^{-1}$ compared to those with higher vigour (Table 7).

\section{Discussion}

The results of this study confirm earlier results indicating that pelleting can reduce both seed viability and rate of germination, especially in the early stages. Blunk et al. (2017), 
Table 6 Sugar beet root yield $\left(\mathrm{t} \mathrm{ha}{ }^{-1}\right)$ in relation to the seed treatment and level of seed vigour in the years 2013-2015

\begin{tabular}{llllllll}
\hline Year & \multicolumn{2}{l}{ Priming method } & & & \multicolumn{2}{l}{ Seed vigour } & \multirow{2}{*}{ Average } \\
\cline { 2 - 3 } & Standard & QB & QB-1 & & Low vigour & High vigour & \\
\hline 2013 & $50.7 \mathrm{a}$ & $49.7 \mathrm{a}$ & $50.9 \mathrm{a}$ & & 48.8 & 52.0 & $50.4 \mathrm{a}$ \\
2014 & $73.2 \mathrm{a}$ & $75.9 \mathrm{ab}$ & $78.3 \mathrm{~b}$ & & 75.5 & 76.1 & $75.8 \mathrm{c}$ \\
2015 & $60.4 \mathrm{a}$ & $66.1 \mathrm{~b}$ & $69.2 \mathrm{~b}$ & & 63.8 & 66.6 & $65.2 \mathrm{~b}$ \\
Average & $61.4 \mathrm{a}$ & $63.9 \mathrm{ab}$ & $66.1 \mathrm{~b}$ & & $62.7 \mathrm{a}$ & $64.9 \mathrm{a}$ & 63.8 \\
\hline
\end{tabular}

Averages from three sites are presented

Table 7 Technological yield of sugar, root yield and percentage of sugar content

\begin{tabular}{|c|c|c|c|c|c|c|}
\hline \multirow[t]{2}{*}{ Priming method } & \multirow[t]{2}{*}{ Root yield $\left(\mathrm{t} \mathrm{ha}^{-1}\right)$} & \multirow{2}{*}{$\begin{array}{l}\text { Root variation coef- } \\
\text { ficient }(\%)\end{array}$} & \multirow[t]{2}{*}{ Sugar content $(\%)$} & \multicolumn{3}{|c|}{ Technological yield of sugar $\left(\mathrm{t} \mathrm{ha}^{-1}\right)$} \\
\hline & & & & Low vigour & High vigour & Average \\
\hline Control & $61.4 \mathrm{a}$ & $52.6 \mathrm{a}$ & 18.21 & $10.43 \mathrm{a}$ & $11.16 \mathrm{a}$ & $10.79 a$ \\
\hline QB & $63.9 \mathrm{ab}$ & $47 b$ & 18.26 & $10.81 \mathrm{a}$ & $11.39 \mathrm{a}$ & $11.10 \mathrm{a}$ \\
\hline QB-1 & $66.1 \mathrm{~b}$ & $47 b$ & 18.32 & $11.00 \mathrm{a}$ & $12.15 b$ & $11.58 \mathrm{~b}$ \\
\hline Average & 63.8 & 48.8 & 18.26 & $10.75 \mathrm{a}$ & $11.56 \mathrm{~b}$ & 11.16 \\
\hline
\end{tabular}

Averages from 3 years and 3 sites are presented

using X-ray computed tomography, observed a delay in seedling growth as an effect of seed pelleting. According to Orzeszko-Rywka and Podlaski (2003), the application of seed pelleting slows water flow from the germination medium through the pellet and pericarp to the seed. As a consequence, the seed germination process is delayed.

Both priming methods positively influenced seed germination ability and speed. The effect on the germination rate expressed as the MGT and the germination ability after 4 days was higher than the priming effect determined after 14 days. This indicates that seed priming has a more significant effect on seed vigour than seed viability (Girolamo and Barbanti 2012). According to earlier research results reported by Orzeszko-Rywka and Podlaski (2003), the efficiency of priming was higher in seeds with lower vigour than those with higher vigour. At the same time, the seeds with a lower level of vigour were characterized by a higher germination ability and speed after priming than non-primed seeds with higher vigour. This again points to the advisability of priming seeds, especially those with lower vigour. As a result, seed loss during treatment can be reduced. According to KHBC data, seed priming reduces losses during the technological process by approximately $20 \%$. The relationship between priming effects and initial seed quality can vary in relation to the plant species and seed treatment. Finch-Savage and Bassel (2016) suggest that species that benefit the most from priming treatments are those with indeterminate floral development and heterogeneous seed development. According to Cantliffe et al. (1987), highly vigorous seeds that are free from pathogens are an essential requisite for good priming results, contrasting with the belief that this technique may improve the performance of seeds of lower quality. The priming efficiency under the conditions of water deficit or excess in the germination medium and a lower temperature $\left(10^{\circ} \mathrm{C}\right.$ vs. $15^{\circ} \mathrm{C}$ ) was greater than that under conditions that were close to optimal. These data confirm the results of other authors (McDonald 2000, Girolamo and Barbanti 2012). The above data also indicate that priming reduces the differences in germination and the course of emergence caused by different levels of seed vigour and germination conditions. It is no wonder that there was a reduction in the coefficient of the root mass variation index at harvest time as a result of priming. This fact indicates that there is a reduction in root losses during harvest (OrzeszkoRywka, and Podlaski 2003). The higher vigour of seeds caused by priming was associated with the acceleration of leaf development and the increase in plant dry matter during the growing season. In the cultivation of sugar beets, every factor accelerating leaf growth at the beginning of the growing season causes an increase in the dry mass of plants (Jaggard et al. 2009). As a result, seed priming contributes to a significant increase in the technological yield of sugar.

It should also be noted that the root yield is less variable during harvesting. In sugar beet plantations, potential yield is lost in non-uniform stands of seedlings because space is inefficiently occupied by 'weaker' seedlings, and this space cannot be fully recovered by the compensatory growth of the more vigorous seedlings. If varieties can be created in which the larger seedlings make up more of the population, then a yield increase of $1 \mathrm{tha}^{-1}$ should be achievable (Jaggard et al. 2009). 


\section{Conclusions}

1. Seed priming reduces the unfavourable effects of pelleting on the germination ability assessed under different environmental conditions.

2. Priming seeds with lower vigour, determined by the increase in germination ability and speed, is more effective than the priming of seeds with higher vigour.

3. Seed priming reduces differences in the germination ability and speed among seed lots with different initial vigour levels.

4. Seed priming reduced the negative effects of a lower temperature and non-optimal humidity conditions in the germination media on the germination rate.

5. Seed priming, especially the more advanced QB-1 technology, improved the germination ability, germination speed and field emergence rate, accelerated leaf area development and initial plant growth and increased the root yield and technological yield of sugar compared to non-primed seeds.

6. Over 3 years, on average, the seeds primed with the QB and QB-1 methods increased in root yield by 2.5 (3.9\%) and $4.7 \mathrm{t} \mathrm{ha}^{-1}(7.3 \%)$, respectively, in relation to the control.

7. Seed priming influenced the root coefficient of variation index determined at harvest time. This value was significantly higher for non-primed seeds, up to $52.6 \%$, while the value for primed seeds was $47.0 \%$.

8. The increase in root yield and sugar content, although not always statistically significant, increased the technological yield of sugar. The QB method increased the sugar yield by $0.31 \mathrm{t} \mathrm{ha}^{-1}$ (difference not significant) relative to the control, while the QB-1 method increased the sugar yield by $0.79 \mathrm{t} \mathrm{ha}^{-1}$ (significant).

Acknowledgements This work was supported by the Ministry of Science and Higher Education of the Republic of Poland (Grant No. PBS1/ A8/15/2013).

\section{Compliance with Ethical Standards}

Conflict of interest The authors declare that they have no conflict of interest.

Open Access This article is distributed under the terms of the Creative Commons Attribution 4.0 International License (http://creativeco mmons.org/licenses/by/4.0/), which permits unrestricted use, distribution, and reproduction in any medium, provided you give appropriate credit to the original author(s) and the source, provide a link to the Creative Commons license, and indicate if changes were made.

\section{References}

Barnes AP, Ferreira J, Revoredo-Giha CRG, Hoad S, Hoebe P, Burnett $F$ (2016) The UK plant breeding sector and innovation (CTRES-042). Report for the Intellectual Property Office, HMSO

Blunk S, Malik AH, de Heer M, Ekblad T, Fredlund K (2017) Quantification of differences in germination behaviour of pelleted and coated sugar beet seeds using x-ray computed tomography (x-ray CT). Biomed Phys Eng Express 3(4):044001

Burks E, XBEET® (2008) Next generation priming. Br Sugar Beet Rev 76:6-9

Cantliffe DJ, Elbala M, Guedes A, Odell GB, Veazie P, Schultheis JR, Seale DN, Shuler KD, Tanne I, Watkins JT (1987) Improving stand establishment of direct-seeded vegetables in Florida. Proc Fla State Hortic Soc 100:213-216

CIBE (2017) Beet seed: Seed survey 2017/18. First indications (D.2004/17). TRCC Meeting, 9 November 2017, Chantilly

Draycott AP (2006) "Sugar beet" Blackwell Publishing Ltd

Evans CG (1972) The Quantitative analysis of plant growth. Studies in Ecology. Volume 1. University of California Press, Berkeley, Los Angeles

Finch-Savage WE, Bassel GW (2016) Seed vigour and crop establishment: extending performance beyond adaptation. J Exp Bot 67(3):567-591

Fischer RA, Edmeades GO (2010) Breeding and cereal yield progress. Crop Sci 50:85-98

Girolamo G, Barbanti L (2012) Treatment conditions and biochemical processes influencing seed priming. Ital J Agron 7(2):e25-e25

Hussain S, Khan F, Hussain HA, Nie L (2016) Physiological and biochemical mechanisms of seed priming-induced chilling tolerance in rice cultivars. Front Plant Sci 7(116): 116

ISTA International Seed Testing Association (1995)

Jaggard KW, Qi A, Ober ES (2009) Capture and use of solar radiation, water, and nitrogen by sugar beet (Beta vulgaris L.). J Exp Bot 60(7):1919-1925

Khan AA (1992) Preplant physiological seed conditioning. Hortic Rev 13:131-181

Lutts S, Benincasa P, Wojtyla L, Kubala S, Pace R, Lechowska K, Quinet M, Garnczarska M (2016) Seed priming: new comprehensive approaches for an old empirical technique. In: Susana Araujo S, Balestrazzi A (eds) New challenges in seed biology-basic and translational research driving seed technology. InTech, Rijeka

McDonald MB (2000) Seed priming. In: Black M, Bewley JD (eds) Seed technology and its biological basis. Sheffield Academic Press, Sheffield, pp 287-325

Noleppa S (2016) The economic, social and environmental value of plant breeding in the European Union.An ex post evaluation and ex ante assessment. HFFA Res Paper 3:1-82

Orzeszko-Rywka A, Podlaski S (2003) The effect of sugar beet seed treatments on their vigour Plant Soil. Environment 49(6):249-254

Paparella S, Araújo SS, Rossi G, Wijayasinghe M, Carbonera D (2015) Seed priming: state of the art and new perspectives. Plant Cell Rep 34(8):1281-1293

Pieper G, Eggebrecht H (1952) Das Saatgut. Wydanie II, Berlin

Podlaski S., Chrobak Z., Wzorek H. 2010. Effects of sugar beet seeds priming. 72nd IIRB Congress, Copenhagen

Publisher's Note Springer Nature remains neutral with regard to jurisdictional claims in published maps and institutional affiliations. 